\title{
ANALYSIS OF SOURCES OF FUNDS FOR INDONESIAN ISLAMIC BANKS
}

\author{
*Mhd Zulkifli Hasibuan ${ }^{1}$, Saparuddin Siregar², Sugianto $^{3}$ \\ ${ }^{1}$ Al Washliyah Nusantara Muslim University \\ ${ }^{2,3}$ North Sumatra State Islamic University \\ Correspondence: zulkiflihasibuan97@gmail.com
}

\begin{abstract}
Islamic banks are banks that carry out business activities based on sharia principles, or Islamic legal principles regulated in the fatwa of the Indonesian Ulema Council such as the principles of justice and balance ('adl wa tawazun), benefit (maslahah), universalism (natural), and do not contain gharar, maysir, usury, injustice and unlawful objects. Funds can also be obtained from own capital, namely by issuing or selling shares. Acquisition of funds is also adjusted to the purpose of the use of these funds. The selection of funding sources will determine the size of the costs borne. Therefore, the selection of sources of funds must be done properly. If the purpose of obtaining funds is for daily activities, the source is clearly different from if the bank wants to make a new investment or to expand a business. Funds needed for the bank's main activities are obtained in various deposits, whereas if the funds needed are used for new investments or business expansion, they are obtained from own capital.
\end{abstract}

Keywords: Islamic Banks, Funds from banks, Funds from the Public, Funds from Other Institutions

\section{INTRODUCTION}

Banking Management in 2000, Kasmir defines the source of bank funds as the bank's efforts to collect funds from the public. According to him, the acquisition of these funds depends on the bank itself, whether from public deposits or from other institutions. Then to finance its operations, funds can also be obtained from own capital, namely by issuing or selling shares. Acquisition of funds is also adjusted to the purpose of the use of these funds. The selection of funding sources will determine the size of the costs borne. Therefore, the selection of sources of funds must be done properly.

The rapid development of the Islamic banking industry is a very interesting and unique phenomenon to study because this phenomenon occurs precisely when the national economy is in an alarming state. Starting with the establishment of PT Bank Muamalat Indonesia, namely as the first Islamic commercial bank in Indonesia, then followed by Bank Mandiri Syariah, until 2004, last July, the conversion of Tugu Commercial Bank from a conventional bank-based bank to a sharia- based bank which is now called Mega Syariah Bank. Indonesia.

In terms of fund distribution, the performance of Bank Syariah Mega Indonesia initially made quite good progress, but after the conversion from a conventional-based bank to a sharia-based bank it continued to experience a decline in performance. This decline in performance is the same as the results of research conducted by Rozak and Mustafa (2008).

\section{IMPLEMENTATION METHOD}

\subsection{Differences between Islamic Banks and Conventional Banks}

The first difference between Islamic banks and conventional banks is in terms of understanding. Islamic banks are banks that carry out business activities based on sharia principles, or Islamic legal principles regulated in the fatwa of the Indonesian Ulema Council such as the principles of justice and balance ('adl wa tawazun), benefit (maslahah), universalism (natural), and do not contain gharar, maysir, usury, injustice and unlawful objects. While conventional banks are banks that carry out conventional business activities which in their activities provide services in payment traffic based on established procedures and provisions. 
The principles of Islamic and conventional banks are actually the same, namely based on economic democracy using the precautionary principle. However, in Islamic banks there are Islamic principles that do not exist in conventional banks.

Islamic banks have a broader function than conventional banks. Although both of them function to collect and distribute public funds, Islamic banks include several other functions, namely Islamic banks carry out social functions in the form of baitul mal institutions; receive funds from zakat, infaq, alms, grants, or other social funds and distribute them to zakat management organizations. In addition, Islamic banks can also collect social funds originating from cash waqf and distribute them to waqf managers (nazhir) in accordance with the will of the waqf giver (wakif). In terms of regulation, supervision of Islamic and conventional banks are both carried out by Bank Indonesia (BI) and the Financial Services Authority (OJK). However, in Islamic banks there is an additional supervisor, namely the Sharia Supervisory Board (DSN). The goal, of course, is to ensure that all Islamic banks operate while complying with Islamic banking principles.

In addition to the board of commissioners and directors as part of the organizational structure in Islamic and conventional banks, in Islamic banks there is a sharia supervisory board in their organizational structure.

The sources of income obtained by Islamic and conventional banks are also different. In Islamic banks the source of income is obtained by a profit-sharing system. The principle of this profitsharing system is the same as trading in general where Islamic banks act as intermediaries between sellers and buyers. The difference in price, among others, is a source of income for Islamic banks. Meanwhile, conventional banks use a fixed interest system. Islamic banks invest only in halal businesses, while conventional banks are not restricted/value-free. In Islamic banks, the amount of profit sharing varies depending on business performance, while in conventional banks the amount of interest is fixed.

1. Funds from the bank itself (First Party Funds)

2. Funds from other institutions (Second Party Funds)

3. Funds from the wider community (Third Party Funds)

According to Wibowo (2007), first-party funds are funds obtained from within the bank. The acquisition of these funds is usually used when the bank has difficulty obtaining funds from outside. One type of first-party funds is paid-in capital from its shareholders. In addition, first-party funds can also be in the form of profit reserves, or profits that have not been shared.

According to Wibowo (2007), the advantage of the first-party source of funds is the relatively smaller reward (profit sharing) compared to borrowing from other institutions. Another advantage is that it is easy to get the desired funds. Meanwhile, the disadvantage is that the relatively large amount of funds must go through various relatively long procedures. Then keep in mind that the use of own funds must be balanced with borrowed funds so that the ratio of the use of borrowed funds and own funds can be optimized in such a way.

According to Dendawijaya (2005), in practice this source of funds is additional if the bank has difficulty in finding sources of first-party or third-party funds. The search for these sources of funds is relatively more expensive and only temporary in nature. Then the funds from this source are used to finance or pay for certain transactions. This source of funds is the most important source of funds for bank operations and is a measure of the success of the bank if it is able to finance its operations from this source of funds. Finding funds from this source is relatively easy when compared to other funding sources.

To obtain funds from the wider community, Islamic banks can use three types of deposits, namely: demand deposits, savings and time deposits. In general, what is meant by demand deposits are deposits which can be withdrawn at any time by using checks, bilyet giro, other means of payment orders or by book-entry (Law No. 10 of 1998 concerning Amendments to Law No. 71992 concerning banking). As for what is meant by sharia demand deposits according to the National Sharia Council, namely demand deposits that are run based on sharia principles. 
In addition to current accounts, other sharia banking products that are included in fundraising products are savings. Based on Law Number 10 of 1998 concerning Amendments to Law Number 7 of 1992 concerning Banking, what is meant by savings are deposits whose withdrawals can only be made according to certain agreed conditions, but cannot be withdrawn by check, bilyet giro, and or other tools that equal to it.

Based on Law Number 10 of 1998 concerning Amendments to Law Number 7 of 1998 concerning Banking, time deposits are deposits whose withdrawals can only be made at certain times according to the agreement between the depositor and the bank concerned. (Ghozali, 2008), As for what is meant by sharia deposits are deposits that are run based on sharia principles. In this case, the MUI National Sharia Council has issued a fatwa stating that deposits that are justified are deposits based on the mudharabah principle.

According to Siregar (2004), in this case Islamic banks act as mudharib (fund managers), while customers act as shahibul maal (fund owners). In its capacity as mudharib, Islamic banks can carry out various kinds of business that do not conflict with sharia principles and develop them, including entering into mudharabah contracts with third parties.

\section{RESULTS AND DISCUSSION}

Considering that Sharia financial awareness and literacy influence the attitudes and intentions of halal industry players to use sharia financial services, the OJK can play a role in initiating increased literacy and education activities regarding sharia finance for halal industry players who are supported by all stakeholders including educational institutions. Furthermore, the policy of increasing the capacity/economic scale of Islamic financial institutions in order to provide superior products for the halal industry, including the implementation of sharia values/principles, lower costs and better services than conventional financial services.

Finally, an integrated cross-sectoral program/policy consists of the sharia finance sector and the real sector (relevant ministries/institutions) to support the creation of a sharia finance ecosystem that encourages product competitiveness and the growth of sharia financial services. Literacy, attitudes, and awareness of Islamic finance greatly affect the intention of halal industry players in using Islamic financial products. In addition, subjective norms, namely one's perception of Islamic finance significantly affect literacy, attitudes and awareness of Islamic finance. In this study it was also found that religiosity did not significantly affect attitudes towards Islamic financial products.

There needs to be an ecosystem synergy between the Islamic finance industry, Islamic social financial institutions and government institutions by emphasizing the role of each institution in developing the real sector or halal industry. If all parties move with integrated goals, the Islamic finance ecosystem will form a strong halal industry community.

\section{CONCLUSION}

The sources of income obtained by Islamic and conventional banks are also different. In Islamic banks the source of income is obtained by a profit-sharing system. The principle of this profitsharing system is the same as trading in general where Islamic banks act as intermediaries between sellers and buyers. The difference in price, among others, is a source of income for Islamic banks. Meanwhile, conventional banks use a fixed interest system. Islamic banks invest only in halal businesses, while conventional banks are not restricted/value-free. In Islamic banks, the amount of profit sharing varies depending on business performance, while in conventional banks the amount of interest is fixed.

\section{REFERENCES}

Arifin, Z. 2006. Fundamentals of Islamic Bank Management. Jakarta: Alphabet Library. Dendawijaya, L. 2005. Banking Management Edition 2. Bogor: Ghalia Indonesia Publisher.

Ghozali, I. 2008. Application of Multivariate Analysis with the SPSS Print IV Program. Semarang: Body 
Diponegoro University Publisher. Mokhtar, M., Smith, P \& Wolf, S. 2005. Measurement and Management of Non-performing Loans in Malaysian Islamic Banks: an Analysis. Islamic Financial Architecture, Risk Management and Financial Stability by Islamic Research and Training Institute. $\quad$ Proceedings. 46. Rosly, SA 2005. Islamic Banking: Doing Things Right and Doing Things Right. Malaysian Journal of Economic Studies. Vol. 42, No. 1 \& 2, pp: 31-40.

Ilham, R. N., Erlina, K. A. F., Silalahi, A. S., Saputra, J., \& Albra, W. (2019). Investigation of the bitcoin effects on the country revenues via virtual tax transactions for purchasing management. Int. J Sup. Chain. Mgt Vol, 8(6), 737.

Nur Ilham, R. ., Arliansyah, A., Juanda, R., Multazam, M. ., \& Saifanur, A. . (2021). RELATHIONSIP BETWEEN MONEY VELOCITY AND INFLATION TO INCREASING STOCK INVESTMENT RETURN: EFFECTIVE STRATEGIC BY JAKARTA AUTOMATED TRADING SYSTEM NEXT GENERATION (JATS-NG) PLATFORM. International Journal of Economic, Business, Accounting, Agriculture Management and Sharia Administration (IJEBAS), 1(1), 87-92. https://doi.org/10.54443/ijebas.v1i1.27

Riinawati, R. (2021). Education Financial Management during Covid-19 Pandemic of Islamic Universities in South Kalimantan. Dinamika Ilmu: Jurnal Pendidikan, 383-396.

Rosly, S. A \& Abu, BA 2003. Performance of Islamic banks and mainstream banks in Malaysia. International Journal of Social Economics. Vol. 30, pp: 1249-1265.

Rozak, D. A \& Mustafa, OM 2008. Consumers' Acceptance on Islamic Home Financing: Empirical Evidence on Bai Bithaman Ajil (BBA) in Malaysia. Pepper presented at IIUM International Accounting Conference IV (INTAV).

Sinta, I. ., Tambarta Kembaren, E. ., \& F, F. (2021). CONJUCTURE EFFECT OF OPERATIONAL COST FOR INCREASING FINANCIAL PERFORMANCE PT. GOTONG ROYONG JAYA. International Journal of Economic, Business, Accounting, Agriculture Management and Sharia Administration (IJEBAS), 1(1), 54-61. https://doi.org/10.54443/ijebas.v1i1.5

Siregar, N. 2004. Analysis of factors influencing the distribution of Islamic banking funds in Indonesia. Unpublished Thesis. University of North Sumatra. Wibowo, MG 2007. The Latest Portrait of Indonesian Sharia Banking (Critical Study of Sharia Banking Development). Yogyakarta: Biruni Press. 